УДК 349.3

DOI https://doi.org/10.32837/pyuv.v0i2(31).566

\author{
М. В. Сокол \\ orcid.org/0000-0001-9530-9753 \\ кандидат юридичних наук, доиент, \\ доиент кафедри иивільно-правових дисииплін \\ Східноєвропейського національного університету ілені Лесі Українки
}

\title{
СІМ'Я ЯК СУБ'ЄКТ СОЦІАЛЬНО-ЗАБЕЗПЕЧУВАЛЬНИХ ПРАВОВІДНОСИН У СФЕРІ ДЕРЖАВНИХ СОЦІАЛЬНИХ ДОПОМОГ
}

Реформування національного законодавства у сфері соціального забезпечення зумовлює необхідність удосконалення правового регулювання як соціально-забезпечувальних, так і інших відносин у галузі надання державних соціальних допомог. Обов'язковим структурним елементом таких правовідносин є суб'єкти, зокрема сім'ї, які отримують і забезпечують надання державної соціальної допомоги.

Визначення правового статусу сімей із дітьми як колективного суб'єкта соціально-забезпечувальних правовідносин є доволі актуальним i дискусійним. Незважаючи на чималу кількість наукових публікацій у цій сфері, сформулювати єдиний підхід поки не вдалося. Найгостріша полеміка ведеться із приводу визнання сім'ї як цілісного суб’єкта галузевих правовідносин чи належності прав і обов'язків у сфері соціального забезпечення окремому члену сім’ї.

У юридичній літературі визначена проблематика відображена у працях: К.В. Бориченко, O.I. Кульчицької, Л.В. Кулачок, С.М. Синчук, I.M Сироти, С.М. Прилипка, О.М. Ярошенка, О.М. Пономаренко, М.В. Філліпової, О.Г. Чутчевої. Незважаючи на наявність широкого кола теоретичних авторських обгрунтувань, єдності щодо розуміння змісту поняття сім'ї як окремого суб'єкта права соціального забезпечення немає.

Мета статті полягає у з'ясуванні сутності сім'ї як колективного суб'єкта соціально-забезпечувальних правовідносин у сфері державних соціальних допомог і визначенні характерних ознак їі правосуб'єктності.

Наявні в науці права соціального захисту наукові погляди на визначення суб'єктного складу отримувачів допомог на дітей не дають однозначної відповіді на поставлене вище питання. Вважається, що до такого складу варто віднести: 1) сім'ю з дітьми загалом, 2) батьків чи одного із них або осіб, які їх замінюють, 3) саму дитину (дітей), 4) дитину (дітей) i, наприклад, матір, котра отримує допомогу для одиноких матерів.

Наукову позицію щодо визнання суб'єктами правовідносин у сфері державних соціальних допомог виключно членів сім’ї розділяють: В.В. Андріїв, Є.Г. Азарова, С.М. Прилипко, О.М. Ярошен- ко та ін. Так, на думку О.М. Пономаренко, навіть у тих випадках, коли в законодавстві йдеться про права та й сім’ї, вони виникають у конкретних ㄲï членів, які й є суб'єктами галузевих правовідносин, а не сім'ї як колективного суб'єкта [1, с. 11].

На користь визнання сім'ї як колективного суб'єкта спрямовані наукові праці O.I. Кульчицької, Л.В. Кулачок, С.М. Синчук, І.М Сироти, М.В. Філліпової, котрі доводять, що право на допомогу у сфері соціального забезпечення виникає лише за умови виховання дитини у в сім'ї, а соціальні кошти, які отримує сім'я, є власністю сім'ї, а не дитини [2, с. 55]. С.М. Синчук вважає, що за сучасних умов є всі правові передумови для визнання сім'ї правосуб'єктною у правовідносинах соціального забезпечення. Авторка зазначає, що сім'я як цілісний суб'єкт реалізовує право на соціальний захист, якщо наслідки соціального ризику є спільними для всіх її членів, а також коли соціального ризику зазнав один із її членів, однак наслідки є вагомими для всієї сім'ї та породжують спільну соціальну потребу [3, с. 210].

Проводячи аналіз ряду законодавчих актів, які містять положення щодо порядку надання соціального забезпечення сім'ям, варто зробити висновок, що коли говориться про сферу соціального страхування, то суб'єктами соціально-забезпечувальних правовідносин виступає здебільшого окремий член сім'ї, а у сфері надання державних соціальних допомог законодавець виділяе сім'ю як колективного суб’єкта, закріплюючи їі права та гарантії у сфері соціального захисту.

Сім'я як цілісний суб'єкт соціально-забезпечувальних правовідносин згадується у Законах України: «Про державні соціальні допомоги сім'ям 3 дітьми» № 2811-XII від 21 листопада 1992 р. [4], «Про соціальну допомогу малозабезпеченим сім'ям» № 1768-III від 01 червня 2000 р. [5], «Про статус і соціальний захист громадян, які постраждали внаслідок Чорнобильської катастрофи» № 796-XII від 28 лютого 1991 р.[6] і підзаконних актах: Постановах КМУ № 250 від 13 березня 2019 р. «Деякі питання надання соціальної підтримки багатодітним сім'ям» [7], № 268 від 28 лютого 2011 р. «Про виплату одноразової винагороди жінкам, яким присвоєно почесне звання 
України «Мати-героїня», та одноразової матеріальної допомоги особам, які постраждали від торгівлі людьми» [8], № 324 від 6 серпня 2014 р. «Про порядок виплати одноразової грошової допомоги особам, які отримали тяжкі тілесні ушкодження під час участі у масових акціях громадського протесту, що відбулися у період з 21 листопада 2013 по 21 лютого 2014 рр.» [9], № 505 від 1 жовтня $2014 \mathrm{p}$. «Про надання щомісячної адресної допомоги внутрішньо переміщеним особам для покриття витрат на проживання, в тому числі на оплату житлово-комунальних послуг» [10].

У теорії права колектив осіб може виступати суб'єктом певних правовідносин за наявності правосуб'єктності. Питання виникнення галузевої правосуб'єктності таких учасників правовідносин завжди має дискусійних характер, оскільки спірним $є$ момент виникнення права та дієздатності.

Правоздатною у сфері соціального забезпечення є сім'я починаючи із моменту її створення. Відповідно до сімейного законодавства сім'я створюється на підставі шлюбу, кровного споріднення, усиновлення, а також на інших підставах, не заборонених законом і таких, що не суперечать моральним засадам суспільства [11, ст. 3]. Законодавство у сфері соціального забезпечення наділяє ознаками галузевої правосуб'єктності ті сім'ї, факт створення яких не завжди можна підтвердити актами громадянського стану. Правові положення Закону «Про соціальну допомогу малозабезпеченим сім'ям» відносять до суб'єктів соціально-забезпечувальних правовідносин сім'ю, яка може підтвердити факт спільного проживання, ведення господарства та наявності взаємних прав і обов'язків.

Нині єдиною законною можливістю визнання факту спільного проживання та ведення господарства $є$ рішення суду, прийняття якого може зайняти тривалий період часу. У такому разі доречними є правові положення окремих європейських держав, де факт наявності сімейних відносин підтверджується нотаріально посвідченим договором, який укладається жінкою та чоловіком, котрі проживають однією сім'єю, але без реєстрації шлюбу. Такі законодавчі нововведення були б доречними і для України, оскільки внесуть чіткість і пришвидшать процедуру встановлення факту виникнення галузевої правосуб'єктності сім'ї, яка має право на отримання державної соціальної допомоги.

Що стосується правоздатності сімей із дітьми як отримувачів ряду державних соціальних допомог, то згідно із Законом України «Про державні соціальні допомоги сім'ям 3 дітьми" сім'єю з дітьми є поєднане родинними зв'язками та зобов'язаннями щодо утримання коло осіб, у якому виховуються рідні, усиновлені діти, а також діти, над якими встановлено опіку чи піклування, прийомні сім'ї, дитячі будинки сімейного типу [4, ст. 2], тобто фактом створення такої сім'ї є момент появи на утриманні та вихованні дитини.

Другим не менш важливим елементом правосуб'єктності сім'ї є галузева дієздатність такого учасника соціально-забезпечувальних правовідносин. Питання моменту виникнення галузевої правосуб'єктності є об'єктом багатьох наукових досліджень. Так, відповідно до наукової позиції К.В. Бориченко момент виникнення дієздатності повністю збігається з моментом виникнення правоздатності. Ця обставина пояснюється тим, що здатність набувати та здійснювати права, а також створювати і виконувати юридичні обов'язки у сфері соціального захисту в особи, а отже, і сім'ї, виникає одночасно з моментом впливу на неї соціального ризику. Соціальні ж ризики у сфері соціального захисту сімей із дітьми завжди пов'язані з утриманням і вихованням дитини [12, с. 136]. Така позиція вбачається обгрунтованою не повною мірою, оскільки, якщо говориться про допомогу для одинокої матері чи допомогу малозабезпеченим сім'ям із дітьми, то факт утримання чи виховання дітей не дозволяє реалізувати право на отримання такої державної соціальної допомоги.

Більш переконливою є думка С.М. Синчук, котра зазначає, що галузева дієздатність сім'ї виникає з моменту настання обставин соціального ризику, яка зумовлює реалізацію права на соціальне забезпечення. Водночас автор виділяє і додаткові умови, за яких сім'я може реалізувати надане їй право на соціальний захист, до яких, наприклад, відносить відсутність додаткових джерел для існування, не вчинення протягом 12 -ти місяців перед зверненням за наданням допомоги покупки, що перевищує 10 -тикратну величину прожиткового мінімуму на сім'ю [3, с. 210]. Наведення таких додаткових умов дієздатності сім'ї у сфері соціального забезпечення $€$ не зовсім правильним, оскільки вони можуть лише обмежувати реалізацію права особи на отримання конкретного виду державної соціальної допомоги, у цьому разі допомоги по малозабезпеченості, але аж ніяк не впливають на момент виникнення галузевої дієздатності сім'ї загалом. Крім того, набуття галузевої дієздатності у сфері соціального забезпечення не варто пов'язувати лише із моментом виникнення обставин соціального ризику. У доктрині права соціального забезпечення ризик є чинником регулювання системи соціального захисту на втрату постійного джерела доходу. Виникнення правовідносин соціального забезпечення пов'язується не лише із втратою доходів, а із настанням складних життєвих i юридично значимих обставин. До складних життєвих обставин насамперед належить малозабезпеченість, а юридично значимими обставинами є народження, усиновлення дитини, встановлення над нею опіки чи піклування, досягнення дітьми відповідного віку, що дає право на 
отримання одноразової винагороди жінкам, яким присвоєно почесне звання України «Мати-героїня» та ін. Варто зауважити, що настання галузевої правосуб'єктності зовсім не залежить від отримуваних сім'єю доходів. Отже, галузева дієздатність сім'ї у сфері надання державних соціальних допомог виникає з моменту настання малозабезпеченості чи юридично значимих обставин, не пов'язаних із отримуваним сім'єю доходом.

У науковій полеміці наявна позиція, що сім'я набуває статусу суб'єкта соціально-забезпечувальних правовідносин у разі, якщо вона відповідає таким ознакам: 1. соціальна потреба, яка виникає внаслідок впливу на сім'ю соціального ризику, є спільною, а тому недоцільно здійснювати соціальне забезпечення щодо кожного їі члена окремо; 2. соціального ризику зазнав один із членів сім'ї, однак його наслідки є вагомими для всієї сім’ї та породжують спільну соціальну потребу [3, с. 210].

Проте, якщо ми говоримо про сім'ю, до складу якої входять діти, то варто також виділити і додаткові особливості правосуб'єктності таких сімей: 1) наявність дітей; 2) встановлений правовий зв'язок між дитиною та суб'єктами, котрі здійснюють за нею догляд (кровний зв'язок, усиновлення, встановлення опіки чи піклування, передання дитини до прийомної сім’ї чи дитячих будинків сімейного типу); 3) спільне проживання дитини з особами, які здійснюють догляд за нею, проте останній критерій не є обов'язковим, адже відповідно до ст. 4 Закону України «Про соціальну допомогу малозабезпеченим сім'ям» до складу сім'ї включаються незалежно від місця проживання (перебування) або реєстрації діти, котрі навчаються за денною формою навчання у закладах загальної середньої, професійної (професійно-технічної), фахової передвищої та вищої освіти до досягнення 23 років і не мають власних сімей [5].

Що стосується першої ознаки - наявності дітей, то варто відзначити, що у Законі «Про державні соціальні допомоги сім'ям 3 дітьми» дитиною вважається особа віком до 18 років, якщо згідно із законом вона не набуває прав повнолітньої раніше. Відповідно до Закону «Про соціальну допомогу малозабезпеченим сім'ям» дитиною може бути визнана й особа старшого віку за умови навчання чи інвалідності.

Характеристика другої ознаки сімей із дітьми дозволяє виділити декілька типів цього колективного суб'єкта.

Кровний зв'язок за народженням свідчить про традиційний тип сім’ї, що складається з батьків і дитини (дітей). Батьками дитини і відповідно членами сім’ї є не тільки чоловік і жінка, які перебувають у зареєстрованому шлюбі, але й ті особи, котрі спільно проживають у фактичних шлюбних відносинах. Підтвердженням цього є ст. $18^{1}$ Закону України «Про державні соціальні допомоги сім'ям 3 дітьми", згідно із якою жінка, що має дітей від особи, з якою вона не перебувала і не перебуває в зареєстрованому шлюбі, але з якою вона веде спільне господарство, разом проживає і виховує дітей, права на одержання допомоги, встановленої на дітей одиноким матерям, не має [4, ст. $18^{1}$ ]. Крім того, до зазначеного типу сімей можуть бути віднесені неповні сім'ї, де дитина виховується одним із подружжя: одинокою матір'ю, одиноким батьком.

Іншим типом сім'ї з дітьми, наближеним до розглянутого вище, є сім'я, заснована на правовому зв'язку усиновленої дитини з усиновлювачем. Право на допомогу при усиновленні дитини має особа, котра є громадянином України, постійно проживає на її території й усиновила дитину з числа дітей-сиріт або дітей, позбавлених батьківського піклування (якщо усиновлювачами є подружжя - один із них на їхній розсуд) [4, ст. $12^{1}$ ]. Варто зауважити, що такий вид допомоги прирівнюється до допомоги у зв'язку із народженням дитини, оскільки виплачується у такому самому розмірі та призначається, якщо звернення за призначенням надійшло не пізніше дванадцяти місяців із дня набрання законної сили рішенням про усиновлення дитини.

Наступним типом сім'ї з дітьми є сім'я, в якій спільно проживають опікун (піклувальник) і дитина, над якою встановлено опіку чи піклування. Інститут опіки і піклування має комплексний характер, оскільки знаходиться у сфері сімейного, цивільно-правового й адміністративно-правового регулювання. Досить важливим є той факт, що надана державна допомога вважається власністю не всієї сім’ї, а власністю дитини, над якою встановили опіку чи піклування.

Правовий зв' язок між дорослою особою та дитиною також виникає у разі, коли дитина передається на виховання до прийомної сім'ї чи до дитячого будинку сімейного типу. Ці правовідносини реалізуються на підставі договору між відповідними особами й органами опіки та піклування. Державна соціальна допомога призначається і виплачується щомісяця у грошовій формі батькам-вихователям на кожну дитину-вихованця і прийомним батькам на кожну прийомну дитину [13].

Виходячи із вищенаведеного, сім'я 3 дітьми $€$ самостійним суб'єктом галузевих правовідносин, що складається з осіб (мінімум двох), які спільно проживають, крім випадку навчання дитини до досягнення нею 23 років, одним із яких виступає неповнолітня особа чи особа віком до 23 років, а також повнолітня особа, котра спільно проживає із батьками на підставі факту встановлення інвалідності, іншими є особи, які здійснюють турботу про дитину та перебувають із нею у відповідному правовому зв'язку. 


\section{Jimepamypa}

1. Пономаренко О.М. Правове регулювання соціального забезпечення допомогами у зв'язку з народженням та вихованням дитини : автореф. дис. ... канд. юрид. наук : 12.00.05. Харків. 2005. 20 с.

2. Советское право социального обеспечения : учебное пособие / Е.Н. Доброхотова, М.В. Филлипова. Санкт-Петербургский государственный университет M.А. Янтураева. Изд-во С.-Петербургского университета, $1992.143 \mathrm{c}$.

3. Синчук С.М. Правосуб'єктність сім'ї у правовідносинах соціального забезпечення. Науковий вісник Міжнародного гуманітарного університету. Серія : Юриспрудениія. 2014. № 8. С. 209-211.

4. Про державну допомогу сім'ям з дітьми : Закон України від 21 листопада 1992 р. № 2811-XII. Відомості Верховної Ради України. 1993. № 5. Ст. 21.

5. Про соціальну допомогу малозабезпеченим сім'ям : Закон України від 01 червня 2000 р. № 1768-III. Відомості Верховної Ради України. 2000. № 35. Ст. 290.

6. Про статус і соціальний захист громадян, які постраждали внаслідок Чорнобильської катастрофи : Закон України від 28 лютого 1991 р. № 796-XII. Відомості Верховної Ради Украӥни. 1991. № 16. Ст. 200.

7. Деякі питання надання соціальної підтримки багатодітним сім'ям : Постанова КМУ № 250 від 13 березня 2019 p. URL: https://zakon.rada.gov.ua/laws/ show $/ 250-2019-\%$ D0\% BF\#Text.

8. Про виплату одноразової винагороди жінкам, яким присвоєно почесне звання України «Мати-героїня», та одноразової матеріальної допомоги особам, які постраждали від торгівлі людьми : Постанова КМУ № 268 від 28 лютого 2011 р. Офіиійний вісник України. 2011. № 20. Ст. 845 .

9. Про порядок виплати одноразової грошової допомоги особам, які отримали тяжкі тілесні ушкодження під час участі у масових акціях громадського протесту, що відбулися у період з 21 листопада 2013 р. по 21 лютого 2014 р. : Постанова КМУ № 324 від 6 серпня 2014 р. Офіційний вісник України. 2014. № 64. Ст. 1777.

10. Про надання щомісячної адресної допомоги внутрішньо переміщеним особам для покриття витрат на проживання, в тому числі на оплату житлово-комунальних послуг : Постанова КМУ № 505 від 1 жовтня 2014 p. № 505. URL: https://zakon.rada.gov.ua/laws/ show $/ 505-2014-\%$ D0\% BF \#Text.

11. Сімейний кодекс України від 10 січня 2002 р. № 2947-III. Відомості Верховної Ради України. 2002. № 21-22. Ст. 135.

12. Бориченко К.В. Сім'я з дітьми як суб'єкт права соціального забезпечення. Науковий вісник Херсонського державного університету. 2016. Вип. 5. Т. 1. C. $134-137$.

13. Деякі питання виплати державної соціальної допомоги на дітей-сиріт та дітей, позбавлених батьківського піклування, грошового забезпечення батькам-вихователям і прийомним батькам за надання соціальних послуг у дитячих будинках сімейного типу та прийомних сім'ях за принципом «гроші ходять за дитиною», оплати послуг із здійснення патронату над дитиною та виплати соціальної допомоги на утримання дитини в сім'ї патронатного вихователя, підтримки ма- лих групових будинків: Затверджено Постановою Кабінету Міністрів України від 26 червня 2019 р. № 552. Урядовий кур’єр. 2019. № 128.

\section{Анотація}

Сокол М. В. Сім'я як суб'єкт соціально-забезпечувальних правовідносин у сфері державних соціальних допомог. - Стаття.

Стаття присвячена дослідження правового статусу сім’ї, в т. ч. сім'ї з дітьми як суб'єкта соціально-забезпечувальних правовідносин у сфері надання державних соціальних допомог. Проводячи аналіз ряду законодавчих актів, які містять положення щодо порядку надання соціального забезпечення сім'ям, зроблено висновок, що коли йдеться про сферу соціального страхування, то суб'єктами соціально-забезпечувальних правовідносин виступає здебільшого окремий член сім'ї, а у сфері надання державних соціальних допомог законодавець виділяє сім'ю як колективного суб'єкта, закріплюючи іï права та гарантії у сфері соціального захисту.

Визначено та проаналізовано особливості правосуб'єктності цих учасників соціально-забезпечувальних правовідносин. Встановлено факт виникнення права та дієздатності сімей. Правоздатність сім'ї як колективного суб'єкта соціального-забезпечувальних правовідносин виникає 3 моменту їі створення. Юридичними фактами, які підтверджують цю дію, є акти громадянського стану, наприклад, взяття шлюбу, усиновлення дитини, а також рішення суду та нотаріально посвідчений договір між чоловіком і жінкою, що встановлює факт наявності сімейних правовідносин (спільне проживання, спільне ведення господарства та взаємні права й обов'язки). Правоздатність сімей iз дітьми виникає з моменту появи на утриманні та вихованні у сім'ї дитини. У свою чергу, галузева дієздатність такого суб'єкта у сфері надання державних соціальних допомог виникає з моменту настання малозабезпеченості чи юридично значимих обставин, не пов'язаних із отримуваним сім'єю доходом.

Зроблено висновок, що додатковими особливостями правосуб'єктності сімей із дітьми є: 1) наявність дітей; 2) встановлений правовий зв'язок між дитиною та суб'єктами, які здійснюють за нею догляд (кровний зв'язок, усиновлення, встановлення опіки чи піклування, передання дитини до прийомної сім'ї чи дитячих будинків сімейного типу); 3) спільне проживання дитини з особами, котрі здійснюють догляд за нею, проте останній критерій не є обов'язковим для всіх правовідносин.

Сформульовано дефініцію сім’ї з дітьми як самостійного суб'єкта галузевих правовідносин: особи (мінімум двоє), які спільно проживають, крім випадку навчання дитини до досягнення нею 23 років, однією 3 яких виступає неповнолітня особа чи особа віком до 23 років, а також повнолітня особа, котра спільно проживає із батьками на підставі факту встановлення інвалідності, інші особи, що здійснюють турботу про дитину та перебувають із нею у відповідному правовому зв'язку.

Ключові слова: державні соціальні допомоги, соціально-забезпечувальні правовідносини, сім'я, сім'я з дітьми, правосуб'єктність. 


\section{Summary}

Sokol M. V. The family as a subject of social security legal relations in the field of state social benefits. Article.

The article is devoted to the study of the legal status of the family, including families with children as a subject of social security relations in the field of state social benefits. Analyzing a number of legislative acts that contain provisions on the procedure for providing social security to families, it was concluded that when it comes to the field of social insurance, the subjects of social security relations is mostly a single family member, and in the field of providing state social benefits legislator distinguishes the family as a collective entity, enshrining its rights and guarantees in the field of social protection.

The peculiarities of the legal personality of the data of the participants of social security legal relations are determined and analyzed. The fact of origin of the right and legal capacity of families is established. The legal capacity of the family as a collective subject of social security relations arises from the moment of its creation. Legal facts confirming this action are acts of civil status, such as marriage, adoption of a child, as well as court decisions and a notarized agreement between a man and a woman establishing the existence of family relations (cohabit- ation, joint management and mutual rights and duties). The legal capacity of families with children arises from the moment of the child's maintenance and upbringing in the family. In turn, the sectoral capacity of such an entity in the field of state social assistance arises from the moment of poverty or legally significant circumstances that are not related to the income received by the family.

It is concluded that additional features of the legal personality of families with children are: 1) the presence of children; 2) a legal relationship has been established between the child and the subjects caring for him / her (blood relationship, adoption, establishment of guardianship or custody, transfer of the child to a foster family or family-type orphanages); 3) cohabitation of the child with the persons who take care of him, but the latter criterion is not mandatory for all legal relations.

The definition of a family with children as an independent subject of sectoral legal relations, which is a person (at least two) who live together, except for the education of a child under 23 years of age, one of which is a minor or a person under 23 years, as well as an adult who lives with his parents on the basis of the fact of disability, others are persons who care for the child and are in a relevant legal relationship with her.

Key words: state social benefits, social security legal relations, family, family with children, legal personality. 